\title{
PACIENTŲ, SERGANČIŲ PIRMO TIPO CUKRINIU DIABETU, SAMPRATA APIE BURNOS SVEIKATA
}

\author{
Meida Vaičelionytė, Kristina Saldūnaitė, Eglẻ Aida Bendoraitienė, Jūratė Zūbienė, \\ Miglė Žemaitienė, Vilija Andruškevičienė \\ Lietuvos sveikatos mokslu universitetas, Medicinos akademija
}

Raktažodžiai: cukrinis diabetas, burnos sveikata, burnos priežiūra.

\begin{abstract}
Santrauka
Tyrimo tikslas - išanalizuoti pacientų, sergančių pirmo tipo cukriniu diabetu, žinias apie burnos sveikatą.

Medžiaga ir metodai.Tyrimas buvo atliekamas Lietuvos sveikatos mokslų universiteto ligoninès Kauno klinikų Endokrinologijos klinikoje. Tyrime dalyvavo128 respondentai. Tyrimo metodas - anketiné apklausa, vykdyta nuo $2019 \mathrm{~m}$. gruodžio 2 d. iki $2020 \mathrm{~m}$. vasario 29 dienos. Dalyvių imtis atsitiktinè.

Gauti rezultatai parode, kad asmenys, kurių HbA1c (glikuotas hemoglobinas) yra blogas, statistiškai reikšmingai dažniau atsakè, kad seilių funkcijos sutrikimus, dantenų uždegimo ir dantų ėduonies simptomus patiria dažniau, lyginant su asmenimis, kuriu HbAlc yra geras $(\mathrm{p}<0,05)$. Nereguliariai maitinasi 65,4 proc. pacientu. Tik 4,7 proc. tiriamujų pavartoję angliavandenių išsivalo dantis, vieną kartą per dieną dantis valo penktadalis ( 25,8 proc.), o tarpdančių nevalo trečdalis (31,3 proc.) respondentų. Pas burnos priežiūros specialistą vieną kartą per metus lankosi apie pusè respondentu (46,9 proc.). 43,8 proc. apklaustujų nežinojo, jog dantenų ligos gali daryti įtaką glikemijos kontrolei, 78,9 proc. iš odontologų ir 82,0 proc. iš burnos higienistų nèra gavę papildomos informacijos apie sergančiujų diabetu burnos priežiūrą, o tik 14,8 proc. respondentų šeimos gydytojas yra rekomendavęs reguliariai lankytis pas burnos priežiūros specialistą. Išvados. Sergantieji cukriniu diabetu dažnai jaučia seilių funkcijos sutrikimų, dantų èduonies ir dantenų uždegimo simptomus. Pacientų mitybos ir burnos higienos įpročiai yra prasti, o sergančiujų cukriniu diabetu informuotumas apie burnos priežiūrą yra nepakankamas.
\end{abstract}

\section{Ivadas}

Cukrinis diabetas (Diabetes mellitus) - lètinè polietiologinè ir polipatogenezinè liga, kuria sergant, dèl absoliutaus ar santykinio insulino stygiaus bei jo veikimo sutrikimų, pakinta medžiagų, pirmiausia angliavandenių, apykaita. Esant insulino trūkumui, vystosi hiperglikemija - gliukozès koncentracijos kraujyje padidejjimas. Dèl to galimi ilgalaikiai ìvairių organų pažeidimai ir jų veiklos sutrikimas[1].

Lietuvos higienos instituto duomenys parodè, kad Lietuvoje $2009 \mathrm{~m}$. buvo užregistruoti 6421 asmenys, sergantys cukriniu diabetu, o 2019 m. šis skaičius padidejo iki 110136 [2].

Pasaulio sveikatos organizacijos ir Tarptautinès diabeto organizacijos duomenimis, cukrinis diabetas yra neinfekcinè liga, kurios paplitimas nuolat dideja ne tik Lietuvoje, bet ir pasaulyje. Tai aktuali sveikatos problema, nes šia liga sergančių žmonių skaičius per 1980-2014 m. laikotarpị išaugo nuo $108 \mathrm{mln}$. iki $422 \mathrm{mln}$. (paplitimas padidejo nuo 4,7 proc. iki 8,5 proc.). Spejama, kad $2045 \mathrm{~m}$. cukriniu diabetu sirgs $629 \mathrm{mln}$. gyventojų [3,4].

Netinkamai gydomas cukrinis diabetas gali daryti ịtaką ne tik vidaus organų funkcionavimui, bet ir burnos būklei. Tarptautine diabeto organizacija teigia, kad esant blogai glikemijos kontrolei, dideja rizika susirgti infekcinemis burnos gleivinès, seilių, periodonto ir dantų ligomis [3]. Atliktų tyrimų duomenys rodo, jog yra ryšys tarp cukrinio diabeto trukmès, kontrolès lygio ir burnos ligų atsiradimo $[5,6]$. A. Khabbaz ir kt. tyrimas atskleide, kad cukriniu diabetu sergantiems asmenims gausiau kaupiasi apnašos ir vystosi sunkesnis dantenų uždegimas [5]. Nors cukrinis diabetas yra vienas iš periodonto ligų rizikos veiksnių, tačiau remiantis $\mathrm{R}$. Leibel ir kitų atlikto tyrimo duomenimis, sisteminis uždegimas, sukeltas dantenų vagelèse esančių bakterijų, daro įtaką audinių jautrumui insulinui. Dèl to gali padidèti gliukozès kiekis kraujyje [7]. M. Bahammam tyrimo duomenys parodé, kad daugelis cukriniu diabetu sergančių pacientų nežino apie diabeto ir burnos ligų tarpusavio sąveiką [8]. Vadinasi, cukrinio diabeto ir burnos ligos yra tarpusavyje glaudžiai susijusios, todèl turi būti skiriamas ypatingas dèmesys jų kontrolei.

Tyrimo tikslas - išanalizuoti pacientų, sergančių pirmo tipo cukriniu diabetu, sampratą apie burnos sveikatą, rizikos veiksnius bei profilaktikos galimybes. 


\section{Tyrimo medžiaga ir metodai}

Vienmomentinis tyrimas buvo vykdomas $2019 \mathrm{~m}$. gruodžio 2 d. -2020 m. vasario 29 d. Lietuvos sveikatos mokslu universiteto ligoninès Kauno klinikų Endokrinologijos klinikoje, cukrinio diabeto ambulatorinio skyriaus, bendrosios endokrinologijos sektoriaus ir diabetologijos sektoriaus padaliniuose. Tyrimo dalyvių atrankos kriterijai: pilnamečiai ir savanoriškai sutikę dalyvauti tyrime pacientai, sergantys I tipo cukriniu diabetu. Tyrime dalyvavo 128 respondentai, parinkti atsitiktinès atrankos būdu. Jų sociodemografinis pasiskirstymas pateikiamas 1 lenteleje.

Tyrimui naudotas tyrimo autoriu sudarytas klausimynas, modifikuotas atlikus mokslinès literatūros analizę. Anketą sudare 36 klausimai.Tyrimui atlikti gautas Lietuvos sveikatos mokslų universiteto Medicinos akademijos Bioetikos komisijos pritarimas (Nr. BCE - BH - (B) - 63).

Statistinè duomenų analizè atlikta naudojant IBM SPSS 22,0 programą. Taikyta aprašomoji statistika (kokybiniams kintamiesiems skaičiuoti procentai, kiekybiniams - vidurkiai, jų 95 proc. pasikliautinieji intervalai, standartinis nuokrypis). Požymių skirstiniai lyginti taikant chi kvadrato kriterijų $\left(\chi^{2}\right)$ bei z testą. Tikrinant statistines hipotezes, pasirinktas 0,05 reikšmingumo lygmuo. Siekiant ịvertinti statistinį ryšio stiprumą tarp kintamujų, taikytas Spearman koreliacijos koeficientas. Koreliacija laikyta labai stipri arba stipri, kai $\pm 0,7$ $\leq \mathrm{r} \leq \pm 1$; vidutinio stiprumo, kai $\pm 0,5 \leq \mathrm{r}< \pm 0,7$; silpna, kai $\pm 0,2 \leq \mathrm{r}< \pm 0,5$; labai silpna, kai $0 \leq \mathrm{r}<0,2$. Sąsajos laikomos statistiškai reikšmingos, kai paklaidos tikimybė $\mathrm{p}<0,05$.

\section{Tyrimo rezultatai ir jų aptarimas}

Anketinès apklausos duomenys parodè, kad trečdalio (26,6 proc.) respondentų glikuotas hemoglobinas (toliau HbA1c) mažesnis negu $7 \mathrm{mmol} / 1,37,5$ proc. $-7,1-8,0$ mmol/l ribose, o 35,9 proc. respondentų HbAlc yra didesnis nei $8,1 \mathrm{mmol} / \mathrm{l}$. Nustatyta, kad 42,5 proc. apklaustujų turi su

1 lentelè. Respondentų sociodemografinè charakteristika.

\begin{tabular}{|l|c|}
\hline Požymiai & Reikšmė, proc.(n) \\
\hline Amžius (vidurkis \pm SD) & $34,46 \pm 11,88$ \\
Amžiaus grupès: & \\
$18-35$ m. & $61,7(79)$ \\
$36-69 \mathrm{~m}$. & $38,3(49)$ \\
\hline Lytis: & $25,8(33)$ \\
vyrai & $74,2(95)$ \\
moterys & \\
\hline Gyvenamoji vieta: & $70,3(90)$ \\
miestas & $17,2(22)$ \\
miestelis & $12,5(16)$ \\
kaimas & $100(128)$ \\
\hline Iš viso & \\
\hline
\end{tabular}

cukriniu diabetu susijusių komplikacijų: diabetinę nefropatiją (20,3 proc.), diabetinę neuropatiją ar neuropatinę diabetinę pèdą (22,7 proc.) ir diabetinę retinopatiją (14,1 proc.).

Mūsų tyrime pastebèta, kad vienas iš dažniausių sergančiujų cukriniu diabetu burnos nusiskundimų yra burnos sausumo pojūtis. Atlikus statistinę duomenų analizę nustatyta, kad 70-80 proc. respondentų, sergančių I tipo cukriniu diabetu, patiria seilių funkcijos pokyčius (burnos sausumą, sumažejusị seilètekị ir klampių, tąsių seilių išsiskyrimą) (1 pav.).

R. Ranjan ir kt. Indijoje atliktas tyrimas taip pat parodè, kad burnos sausumas ir sumažejęs seilètekis yra paplitęs tarp 40-80 proc. pacientų, sergančių cukriniu diabetu [9]. Seilių funkcijos pokyčiai gali būti susiję su didele gliukozès koncentracija kraujyje, ligos trukme, amžiumi ir cukrinio diabeto komplikacijomis. Pastebeta tendencija, kad asmenys, kurių ligos trukmė yra ilgesnè, HbA1c kontrolè yra blogesnè. Šie pacientai įprastai yra vyresnio amžiaus ir linkę turèti komplikacijų, susijusių su cukriniu diabetu. Asmenys, turintys komplikacijų, dažnai vartoja medikamentus, kurie gali turèti įtakos burnos sausumo išsivystymui (pvz., anticholinerginiai, antihipertenziniai preparatai, diuretikai).

Mūsų tyrime nustatyta, kad respondentai, kurių HbA1c yra daugiau negu $8 \mathrm{mmol} / 1$, dažniau patiria burnos ertmès sausumą, sumažèjusị seilètekị ir klampių, tąsių seilių išsiskyrimą lyginant su asmenimis, kurių HbA1c yra mažiau nei $7 \mathrm{mmol} / \mathrm{l}$. Asmenys, kurių HbA1c buvo didesnis negu $8 \mathrm{mmol} / 1$, statistiškai reikšmingai dažniau atsakè, jog burnos sausumą patiria kelis kartus per mènesị, lyginant su tais, kurių HbAlc buvo mažesnis negu $8 \mathrm{mmol} / \mathrm{l}$ (2 pav.).

Tyrimo metu nustatyta statistiškai reikšminga koreliacija tarp HbA1c kontrolès lygio ir seilių funkcijos sutrikimų. Pastebèta, kad kuo didesnè HbA1c reikšmè, tuo dažniau asmenys patiria sausumo pojūti burnoje - nustatytas labai silpnas teigiamas statistiškai reikšmingas koreliacijos koeficientas $(\mathrm{r}=0,181, \mathrm{p}<0,05)$.

Mūsų tyrime pastebèta, kad penktadalis (21,9 proc.) respondentų jaučia klampių, tąsių seilių išsiskyrimą keletą kartų per savaitę, o 22,7 proc. tai patiria keletą kartų per mè-

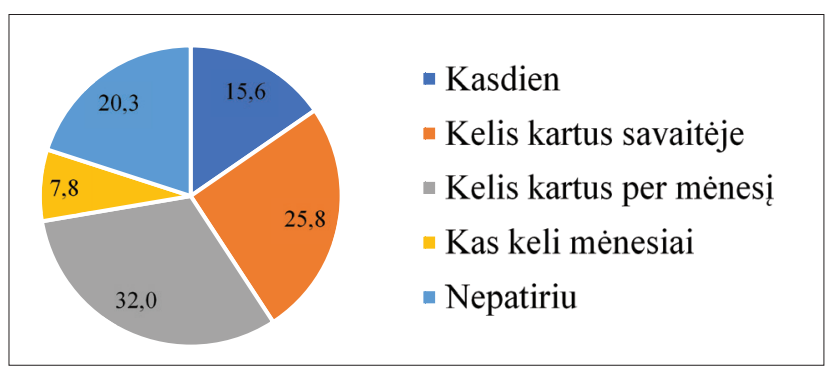

1 pav. Sausumo jausmo burnoje dažnis (proc.) 
nesị. Nustatyta, kad pacientai, kurių $\mathrm{HbA} 1 \mathrm{c}$ yra daugiau negu 8,0 $\mathrm{mmol} / \mathrm{l}$, dažniau patiria klampių, tąsių seilių išsiskyrimą kasdien ir kelis kartus per savaitę, lyginant su asmenimis, kurių $\mathrm{HbA} 1 \mathrm{c}$ yra $7,1-8,0 \mathrm{mmol} / 1$ ribose (3 pav.).

Tarp HbA1c reikšmių ir sumažějusio seilètekio pojūčio bei klampių, tąsių seilių išsiskyrimo gauti silpni teigiami statistiškai reikšmingi koreliacijos koeficientai (atitinkamai $\mathrm{r}=0,435, \mathrm{p}<0,01$ ir $\mathrm{r}=0,396, \mathrm{p}<0,01)$. Tai reiškia, kad respondentai, kurių gliukozès koncentracijos kraujyje lygis yra didesnis, dažniau patiria sumažèjusio seilètekio ir klampių, tąsių seilių išsiskyrimo pojūtį, negu asmenys, kurių gliukozès koncentracijos lygis kraujyje mažesnis.

Epidemiologinių tyrimų rezultatai rodo, kad sergančiujų cukriniu diabetu dantenų ligų rizika yra tris kartus didesné, lyginant su nesergančiaisias šia liga $[10,11]$. Hipotetiškai teigiama, kad vienas iš pagrindinių dantenų ligų atsiradimą predisponuojančių veiksnių yra prasta gliukozès kontrolè. Išsiaiškinta, kad pusė respondentų patiria dantenų paraudimą ir patinimą, didžioji dalis $(88,3$ proc.), valydamiesi dantis šepetèliu, patiria dantenų kraujavimą, o spontaninį dantenų kraujavimą patiria 18,7 proc. cukriniu diabetu sergančiu asmenų. F. Torres ir kt. tyrimo rezultatai parode, kad dantenų uždegimas yra paplitęs tarp 15,0 proc., o periodontitas $-5,0$ proc. pacientų, sergančių I tipo cukriniu diabetu [12]. Pastebèta, kad asmenys, kurių HbA1c yra daugiau nei $8 \mathrm{mmol} / 1$, valydamiesi dantis šepetèliu dantenų kraujavimą patiria statistiškai reikšmingai dažniau, lyginant su pacientais, kurių HbA1c yra mažiau nei 7 mmol/1 (4 pav.).

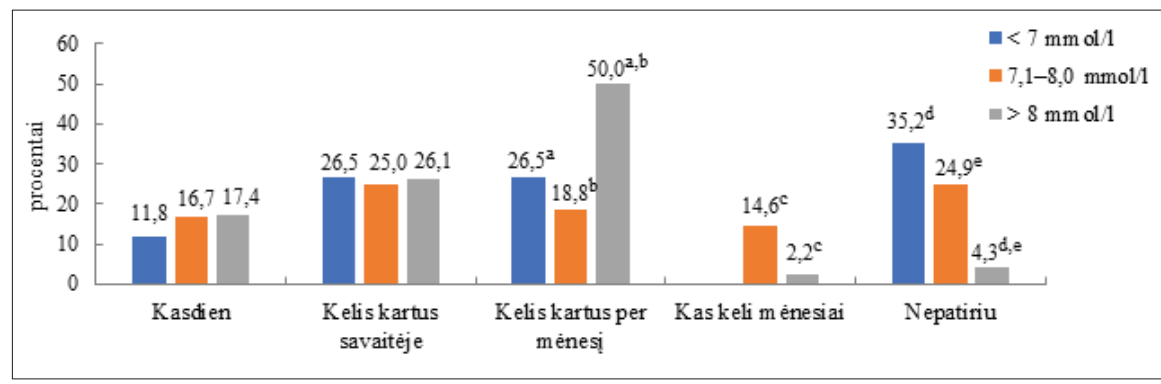

2 pav. Burnos sausumo priklausomybė nuo HbA1c reikšmės (proc.) $\chi^{2}=26,806,11 \mathrm{~s}=8,{ }^{\mathrm{a}, \mathrm{b}, \mathrm{c}, \mathrm{d}, \mathrm{e}} \mathrm{p}<0,05$

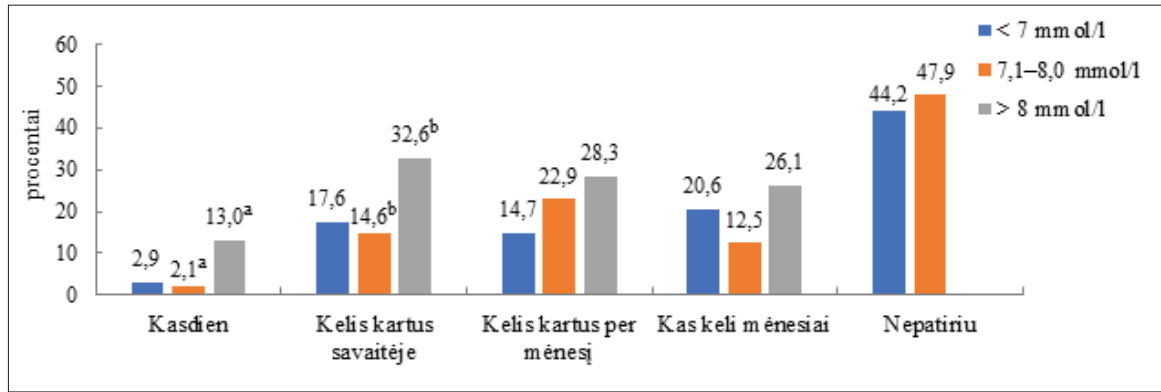

3 pav. Klampių, tąsių seilių išsiskyrimo priklausomybė nuo HbA1c reikšmės (proc.) $\chi^{2}=34,441,11 \mathrm{~s}=8,{ }^{\mathrm{a}, \mathrm{b}} \mathrm{p}<0,05$

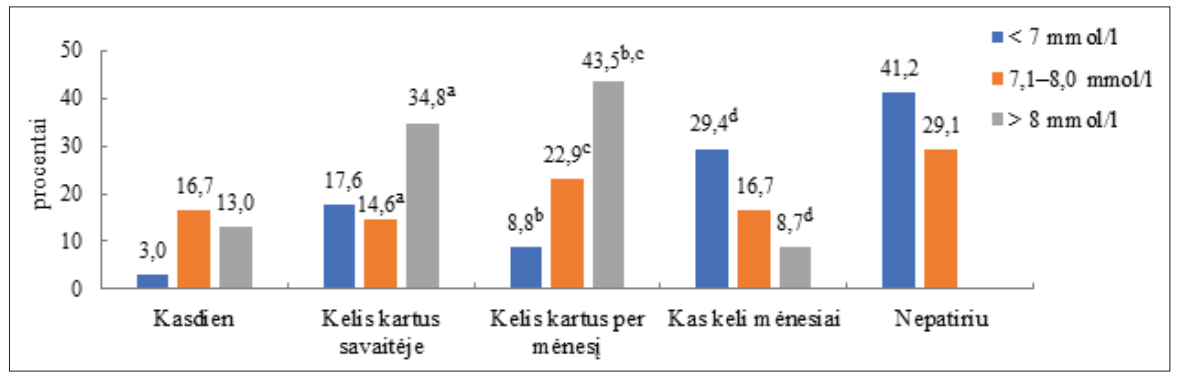

4 pav. Dantenų kraujavimo, valantis dantis šepetėliu, priklausomybė nuo HbA1c reikšmės (proc.) $\chi^{2}=39,186,11 \mathrm{~s}=8,{ }^{\mathrm{a}, \mathrm{b}, \mathrm{c}, \mathrm{d}} \mathrm{p}<0,05$

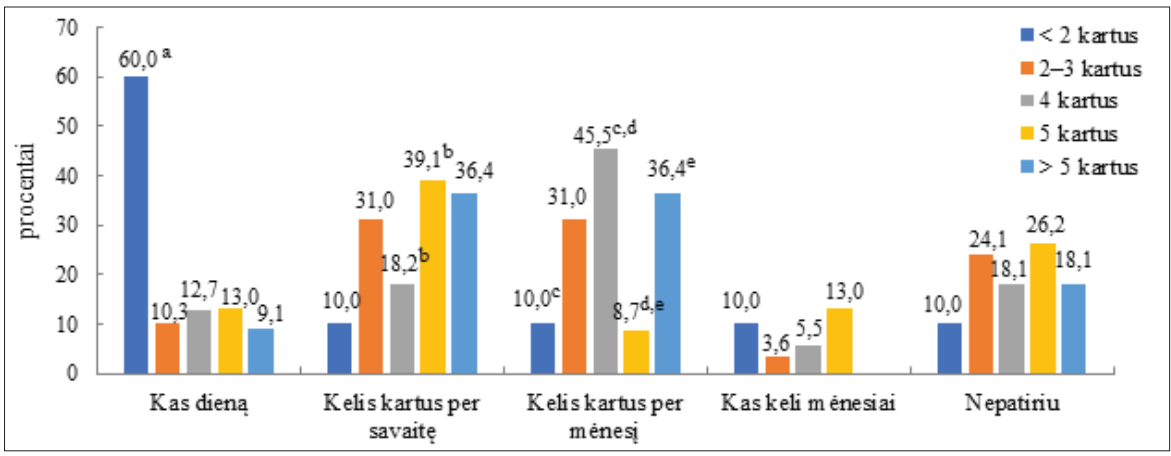

5 pav. Burnos sausumo priklausomybè nuo valgymo dažnio (proc.) $\chi^{2}=31,271,11 \mathrm{~s}=16,{ }^{\mathrm{a}, \mathrm{b}, \mathrm{c}, \mathrm{d}, \mathrm{e}} \mathrm{p}<0,05$ 


\section{4}

A. Meenawat ir kt. atliktame tyrime taip pat gautas statistiškai reikšmingas ryšys tarp blogos glikemijos kontrolès ir didesnès dantenų kraujavimo po zondavimo indekso reikšmès [6]. Pastebètos statistiškai reikšmingos koreliacijos tarp $\mathrm{HbA} 1 \mathrm{c}$ reikšmės ir dantenų uždegimo požymių. Nustatyta, kad respondentai su didesniu $\mathrm{HbA} 1 \mathrm{c}$ rodikliu dažniau patiria dantenų patinimą - nustatytas silpnas teigiamas statistiškai reikšmingas koreliacijos koeficientas $(\mathrm{r}=0,214$, $\mathrm{p}$ $<0,05)$. Silpni teigiami statistiškai reikšmingi koreliacijos koeficientai nustatyti tarp HbA1c kontrolès lygio ir dantenu kraujavimo valantis dantis šepetėliu bei spontaninio dantenu kraujavimo (atitinkamai $\mathrm{r}=0,423, \mathrm{p}<0,01$ ir $\mathrm{r}=0,219, \mathrm{p}$ $<0,05)$. A. Jindal ir bendraautorių atlikto tyrimo duomenys patvirtina gautus rezultatus. Jų tyrimas įrodo, kad pacientai, kurių HbA1c kontrolè yra bloga, dažniau jaučia dantenų uždegimo požymius, lyginant su tais, kurių HbA1c kontrolè yra gera [13]. A. Pranckevičienės tyrime statistiškai reikšmingo ryšio tarp glikemijos kontrolès lygio ir periodonto audinių pažeidimo sunkumo nebuvo [10]. Mūsų tyrime nustatyta, kad pacientams, turintiems su cukriniu diabetu susijusių komplikacijų, statistiškai reikšmingai dažniau kas keletą mėnesių parausta dantenos, lyginant su asmenimis, kuriems tokių komplikacijų nebuvo (atitinkamai 38,9 proc. ir 20,3 proc.) $(\mathrm{p}<0,05)$. Vertinant santyki tarp cukrinio diabeto komplikacijų ir atipinių pojūčių burnos ertmèje tyrimo rezultatų, pastebetas silpnas teigiamas statistiškai reikšmingas koreliacijos koeficientas tarp komplikacijų ir dantenų paraudimo $(\mathrm{r}=0,248, \mathrm{p}<0,01)$ ir labai silpnas teigiamas statistiškai reikšmingas koreliacijos koeficientas tarp komplikacijų ir dantenų patinimo $(r=0,197, \mathrm{p}<0,05)$. A. Meenawat ir kt. tyrimas patvirtina gautus rezultatus. Nustatyta, jog cukrinio diabeto komplikacijos statistiškai reikšmingai veikia periodonto sveikatos būklę [6]. Pastebima tendencija, kad pacientai, turintys cukrinio diabeto komplikacijų, yra linkę blogiau kontroliuoti glikemijos lygi kraujyje, dèl to susilpneja vietinis imuninis organizmo gynybos mechanizmas ir vystosi lėtinis uždegimas, kuris skatina dantenų ligų atsiradimą. Dantenų ligų išsivystymui įtakos gali turèti vyresnis paciento amžius ir ilgesnè ligos trukmè. A. Pranckevičienès tyrimo metu nustatytos statistiškai reikšmingos sąsajos tarp vyresnio paciento amžiaus (daugiau nei $45 \mathrm{~m}$.) bei ilgesnès negu $12 \mathrm{~m}$. ligos trukmės ir didesnių periodonto ligos vertinimo reikšmių [10].

Nors cukrinio diabeto ir dantų èduonies ryšio teorija diskutuotina, hipotetiškai teigiama, kad dantų èduonies paplitimas tarp sergančiųjų cukriniu diabetu gali būti didesnis dèl blogos glikemijos kontrolès, kuri sukelia burnos sausumą ir sumažina seilètekį, o šis - dantų edduonies išsivystymą, lyginant su nesergančiais cukriniu diabetu [11]. Mūsų tyrimo metu nustatyta, kad pusè (49,3 proc.) sergančiųų cu- kriniu diabetu patiria dantų skausmą, iš kurių dažnas $(37,5$ proc.) jaučia ji kas keleri mėnesiai. Dantų jautrumą šalčiui, karščiui, saldžiam ir rūgščiam maistui patiria didžioji dalis (75,9 proc.) respondentų. F. Torres ir kt. tyrime pastebėta, kad sergantiems cukriniu diabetu dažniausiai pasireiškianti komplikacija (58,3 proc.) yra dantų eduonis, nustatomas 23,3 proc. pacientų, turinčių burnos sausumą [12]. Išsiaiškinta, kad asmenys, kurių HbAlc yra daugiau nei $8 \mathrm{mmol} / \mathrm{l}$, statistiškai reikšmingai dažniau (39,2 proc.) keletą kartu per savaitę patiria dantų jautrumą, lyginant su pacientais, kurių HbAlc mažiau negu $8 \mathrm{mmol} / 1$ ( 8,3 proc. ir 11,8 proc.) $(\mathrm{p}<0,05)$. Ivertinus santykị tarp gliukozès kiekio kraujyje ir dantu skausmo bei jautrumo šalčiui, karščiui, rūgščiam ir saldžiam maistui, pastebèta silpna teigiama statistiškai reikšminga koreliacija (atitinkamai $r=0,276, p<0,01$ ir $r$ $=0,267, p<0,01)$. S. Lai ir kt. tyrimo rezultatai įrodo, kad esant blogai glikemijos kontrolei, dantų éduonies paplitimas yra didesnis (46 proc.), lyginant su tais, kuriu glikemijos kontrolè gera (30 proc.) [14]. A. Coelho ir kt. tyrimo metu nebuvo gautos statistiškai reikšmingos sąsajos tarp HbA1c reikšmés ir éduonies pažeistų, plombuotų ir išrautų dantų indekso. Tiek mūsų, tiek A. Coelho ir kt. tyrime statistiškai reikšmingo skirtumo tarp ligos trukmès ir dantų èduonies nenustatyta [15].

Nemažiau svarbus yra kitas predisponuojantis cukrinio diabeto ir burnos sveikatos veiksnys - paciento mityba. Mūsų tyrimo metu nustatyta, jog 43,0 proc. pacientu valgo keturis kartus per dieną, 18,0 proc. - penkis, 8,6 proc. - daugiau negu penkis kartus per dieną, o beveik trečdalis $(28,1$ proc.) apklaustujų užkandžiauja 2-3 kartus per dieną. Panašius rezultatus savo tyrime gavo ir M. Farooq su bendraautoriais. Tyrẻjai nustatė, kad 18,9 proc. pacientų, sergančių cukriniu diabetu, valgo keturis kartus, o 15,6 proc. - penkis kartus per dieną. Mūsų tyrimo rezultatai parodè, jog nereguliariai maitinasi daugiau negu pusè (66,4 proc.) pacientų. Analogiškai M. Farooq ir kt. atliktame tyrime gauta, kad 63,9 proc. pacientų maitinasi nereguliariai [16]. Pastebėta, kad trečdalis pacientų, kurie valgo penkis kartus per dieną, statistiškai reikšmingai dažniau kelis kartus per savaitę patiria burnos sausumą, lyginant su tais, kurie valgo keturis kartus per dieną $(\mathrm{p}<0,05)(5$ pav. $)$.

Remiantis gautais tyrimo rezultatais, pastebima tendencija, jog pacientai, kurie valgo dažniau, yra linkę dažniau užkandžiauti, o jų maitinimasis dažniau nereguliarus. Nustatyti silpni ir labai silpni teigiami statistiškai reikšmingi koreliacijos koeficientai tarp užkandžiavimo dažnio ir valgymo dažnio bei reguliarumo (atitinkamai $r=0,252, p<0,05$ ir $\mathrm{r}=0,174, \mathrm{p}<0,01)$. Mūsų tyrime pastebèta, kad kuo tiriamieji dažniau valgè, tuo dažniau patyrè klampių, tąsių seilių išsiskyrimą - nustatytas labai silpnas teigiamas statistiškai 
reikšmingas koreliacijos koeficientas $(r=0,177, p<0,05)$.

C. Palacios ir kt. atliktame tyrime gauta, kad asmenu, per dieną suvartojančių daugiau angliavandenių ( $>260 \mathrm{~g} / \mathrm{d})$, statistiškai reikšmingai didesnè dantų èduonies atsiradimo rizika, lyginant su tais, kurie angliavandenių suvartoja mažiau ( $<155 \mathrm{~g} / \mathrm{d})$ [17]. Pastebima tendencija, kad sergantieji cukriniu diabetu gliukozès kiekiui kraujyje normalizuoti vartoja lengvai fermentuojamus angliavandenius. Mūsų tyrimo rezultatai rodo, jog pusè (53,1 proc.) pacientų gliukozès kiekiui kraujyje normalizuoti naudoja saldainius, trečdalis ( 34,4 proc.) - sultis, o ketvirtadalis (27,3 proc.) - gliukozę. M. Farooq ir kt. atliktame tyrime nustatyta, kad 17,8 proc. pacientų yra linkę vartoti saldainius, o $H$. Thanh ir kt. tyrime pastebeta, kad sultis vartoja 7,0 proc. pacientų, vaisius $-6,5$ proc., o cukrų ir medu - 6,5 proc. [16,18]. Lengvai fermentuojami angliavandeniai yra rūgštis produkuojančiu bakterijų substratas, joms veikiant burnos ertmès $\mathrm{pH}$ rūgštejja ir demineralizuoja danties audinius. Kitas svarbus veiksnys yra seilètekis, kuris nakties metu sumažeja, dèl to pablogėja savaiminis burnos apsivalymas ir sudaromos palankios sąlygos dantų ėduonies išsivystymui, todèl dantų valymas po hipoglikemijos nakties metu yra būtinas. Remiantis mūsų tyrimo apklausos atsakymų rezultatais, didžioji respondentų dalis ( 85,2 proc.) hipoglikemijos epizodus patyrè naktị, tačiau tik maža dalis $(4,7$ proc.) išsivalo dantis po angliavandenių pavartojimo. A. Coelho ir bendraautorių tyrime pastebèta, kad tik vienas iš apklaustujų nakties metu išsivalo dantis po angliavandenių pavartojimo gliukozès koncentracijai kraujyje normalizuoti [15]. Manoma, kad toks rezultatas gali būti susijęs su pacientų žinių trūkumu ir motyvacijos stoka.

Burnos higiena yra viena iš pagrindinių burnos ertmès ligų prevencijos priemonių, tačiau mūsų tyrimo rezultatai parodè, kad 63,2 proc. asmenų, sergančių cukriniu diabetu, dantis valo du kartus per dieną, o penktadalis ( 25,8 proc.) - vieną kartą per dieną ar rečiau. Panašius rezultatus galime ižvelgti ir A. Coelho ir kt. tyrime, kurio rezultatai parodè, jog 80 proc. pacientų dantis valo du kartus, o 20 proc. - vieną kartą per dieną [15]. M. Bahammam tyrime pastebėta, kad 22,2 proc. pacientu dantis valo du kartus per dieną, o Y. Basil ir kt. tyrime nustatytas dar mažesnis $(19,1$ proc.) pacientų, kurie dantis valo du kartus per dieną, paplitimas. Šių autorių aprašytų tyrimų rezultatai rodo, kad 45,6 proc. pacientų dantis valo vieną kartą per dieną $[8,19]$. Mūsų tyrime nustatyta labai silpna teigiama statistiškai reikšminga koreliacija $(\mathrm{r}=$ $0,178, p<0,05)$ tarp dantų valymo ir hipoglikemijos nakties metu dažnių. Vadinasi, respondentai, kurie dantis valosi rečiau, yra dažniau linkę patirti hipoglikemijas naktį. Pastebeta, kad trečdalis (31,3 proc.) asmenų, sergančių cukriniu diabetu, niekada nevalo tarpdančių, o tik 18,0 proc. valo vieną kartą per dieną. Panašūs rezultatai buvo gauti Y. Basil ir kt. tyrime, o M. Bahmmam tyrimo rezultatai rodo, jog cukriniu diabetu sergančių asmenų tarpdančių valymo dažnis dar mažesnis: 3,1 proc. valo vieną kartą, o 73,6 proc. niekada nevalo tarpdančių $[8,19]$. Mūsų tyrimo rezultatų analizè parodè, kad kuo didesnè HbA1c reikšmè, tuo rečiau asmenys valosi dantis - nustatytas silpnas teigiamas statistiškai reikšmingas koreliacijos koeficientas $(r=0,240, p<0,01)$. Asmenys, kurių HbAlc reikšmė didesnè nei $8 \mathrm{mmol} / \mathrm{l}$, dažniau linkę valyti dantis vieną kartą per dieną, lyginant su pacientais, kurių HbA1c mažiau negu $7 \mathrm{mmol} / \mathrm{l}(\mathrm{p}<0,05)$. Respondentai, kurie dantis valo vieną kartą per dieną, statistiškai reikšmingai dažniau atsakè, jog dantų skausmą patiria kas keleri mėnesiai, o dantų jautrumą šalčiui, karščiui, rūgščiam, saldžiam maistui patiria keletą kartų per savaitę, lyginant su asmenimis, kurie dantis valo du kartus per dieną (atitinkamai 57,6 proc., 29,6 proc. ir 39,4 proc., 13,6 proc.) $(\mathrm{p}<0,05)$. S. Lai ir kt. tyrimo rezultatai patvirtino, kad pacientai, kurių glikemijos kontrolè bloga, dažniau linkę dantis valytis nereguliariai arba vieną kartą per dieną, lyginant su pacientais, kurių glikemijos kontrolè yra gera [14]. Galime daryti prielaidą, kad tokius tyrimo rezultatus galejjo nulemti pacientų motyvacijos ir žinių trūkumas.

Išanalizavus mūsų tyrimo rezultatus, nustatyta, jog didžioji dalis cukriniu diabetu sergančių asmenų žino, kad cukrinis diabetas yra rizikos veiksnys dantų èduonies ir dantenų ligų išsivystymui. Y. Basil ir kt. aprašytame tyrime 75,9 proc. pacientų mané, jog cukrinis diabetas gali turèti įtakos dantenų ligų atsiradimui [19]. Mūsų tyrime pastebèta, kad tik 43,8 proc. sergančiujų cukriniu diabetu žino, jog dantenų ligos gali daryti ịtaką hiperglikemijai. M. Bahammam atliktas tyrimas ịrodo, kad beveik pusè (46,7 proc.) pacientų žino, jog esant blogai glikemijos kontrolei padidejja tikimybè išsivystyti dantenų ligoms, tačiau tik penktadalis $(21,8$ proc.) mano, kad dantenų ligos turi įtakos glikemijos kontrolei [8].

Mūsų tyrime pastebima, kad nedidelè dalis cukriniu diabetu sergančių asmenų yra gavę šeimos gydytojų ir endokrinologų rekomendacijas reguliariai lankytis pas burnos priežiūros specialistus. M. Bahammam nustatè, jog 5,2 proc. pacientų šeimos gydytojas yra rekomendavęs reguliariai lankytis pas burnos priežiūros specialistą [8]. Mūsų tyrimo rezultatai rodo, kad pas odontologą ar burnos higienistą profilaktiškai lankosi apie pusė respondentų. F. Torres ir kt. atliktame tyrime gauti panašūs rezultatai, o Y. Basil ir kt. tyrime pastebėtas dar mažesnis (15,1 proc.) pacientų, profilaktiškai lankančių burnos priežiūros specialistą, paplitimas $[12,19]$. Pastebèta, kad beveik pusè (46,9 proc.) respondentų pas burnos priežiūros specialistą profilaktiškai lankèsi vieną kartą per pastaruosius metus, o ketviradalis (22,7 proc.) nurodè, jog nesilankè. F. Torres ir kt. atliktame tyrime gauta, kad 40 proc. pacientų pas burnos priežiūros specialistą lankosi vieną 
kartą per metus [12]. Daugiau nei pusė tiriamujų (57,8 proc.) lankèsi pas odontologą ir beveik pusè ( 43,0 proc.) pas burnos higienistą, atsiradus ligos požymių (dantų skausmui, apnašoms, akmenims, dantenų kraujavimui). Niekada nesilankẻ pas burnos higienistą 14,8 proc. respondentų. S. Lai ir kt. tyrime pastebèta, kad pacientai, kurių HbA1c kontrolè bloga, linkę dažniau lankytis pas burnos priežiūros specialistą, kai atsiranda ligos požymių (pvz., skausmas), lyginant su tais, kurių HbA1c kontrolè yra gera [14]. Galima teigti, kad esant informuotumo trūkumui, pacientai nežino, kaip tinkamai prižiūrèti burnos ertmę sergant cukriniu diabetu, todèl tai gali daryti įtaką jų burnos sveikatai.

\section{Išvados}

1. Apie 80 proc. respondentų, sergančių pirmo tipo cukriniu diabetu, patiria seilių funkcijos pokyčius, kurie sukelia dantų ėduonies ir dantenų ligų išsivystymo riziką.

2. Didžiosios dalies respondentų, sergančių pirmo tipo cukriniu diabetu, mitybos ịpročiai yra blogi.

3. Pacientams, sergantiems pirmo tipo cukriniu diabetu, trūksta žinių apie burnos higieną: penktadalis $(25,8$ proc.) dantis valo vieną kartą per dieną, trečdalis (31,3 proc.) nevalo tarpdančių. Pusė sergančiųjų cukriniu diabetu lankosi pas burnos priežiūros specialistą, kai atsiranda ligos požymių, o profilaktinių vizitų dažnis yra per mažas. Nustatyta, kad pacientams sveikatos priežiūros specialistai nèra suteikę rekomendacijų apie reguliarų lankymąsi pas burnos priežiūros specialistą, o papildomos informacijos apie burnos priežiūrą, sergant šia liga, sklaida yra nepakankama.

\section{Literatūra}

1. Naudžiūnas A., Sadauskas S., Unikauskas A., Jankauskienė L., Leišytė P., Kalinauskienė E. M. E. Vidaus ligų pagrindai odontologams. Kaunas, 2010.

2. Lietuvos higienos institutas. Sveikatos statistinių duomenų portalas. 2019.

https://stat.hi.lt/default.aspx?report_id=168

3. International Diabetes Federation. IDF diabetes atlas update poster, 7th edition. Chapter 3: the global picture. Brussels 2017:50-4.

http://www.diabetesatlas.org/

4. World Health Organization. Global report on diabetes. Library cataloguing-in-publication. 2016.

https://apps.who.int/iris/bitstream/

handle/10665/204871/9789241565257_eng.pdf

5. Al-Khabbaz A, Al-Shammari K, Hasan A, Abdul-Rasoul M. Periodontal health of children with type 1 diabetes mellitus in Kuwait: a case-control study. Med Princ Pract 2013;22:144-9. https://doi.org/10.1159/000342624

6. Meenawat A, Punn K, Srivastava V, Meenawat A, Dolas R,
Govila V. Periodontal disease and type I diabetes mellitus: Associations with glycemic control and complications. J Indian Soc Periodontol 2013;17:597.

https://doi.org/10.4103/0972-124X.119286

7. Leibel R, Paster B, Desvarieux M, Jr DRJ. The subgingival microbiome, systemic inflammation and insulin resistance: the oral infections, glucose intolerance and insulin: resistance study (ORIGINS). HHS Public Access 2018;44:255-65. https://doi.org/10.1111/jcpe.12664

8. Bahammam M. Periodontal health and diabetes awareness among Saudi diabetes patients. Patient Prefer Adherence 2015;9:225-33.

https://doi.org/10.2147/PPA.S79543

9.Ranjan R, Rajan SY. Oral health manifestations in diabetic. International Journal of Community Health and Medical Research 2016;2:58-62.

10. Pranckevičienė A. 1 ir 2 tipo cukriniu diabetu sergančių pacientų periodontito sunkumo ir chirurginio gydymo efektyvumo ilgalaikis tyrimas. Daktaro disertacija. Kaunas: Lietuvos sveikatos mokslų universitetas, 2017.

11. Kudiyirickal MG, Pappachan JM. Diabetes mellitus and oral health. Endocrine 2015;49:27-34.

https://doi.org/10.1007/s12020-014-0496-3

12. Torres FM, Mazzini WU, Campuzano TM. Predisposing factors affecting oral health in diabetes mellitus patients. Rev Odontológica Mex 2017;21:e101-6.

https://doi.org/10.1016/j.rodmex.2017.05.014

13. Jindal A, Parihar AS, Sood M, Singh P, Singh N. Relationship between severity of periodontal disease and control of diabetes (glycated hemoglobin) in patients with type 1 diabetes mellitus. JIOH 2015;7:17-20.

14. Lai S, Cagetti MG, Cocco F, Cossellu D, Meloni G, Campus $\mathrm{G}$, et al. Evaluation of the difference in caries experience in diabetic and non-diabetic children - a case control study. PLoS One 2017;12:1-13. https://doi.org/10.1371/journal.pone.0188451

15. Coelho A, Paula A, Mota M, Laranjo M, Abrantes M, Carrilho $\mathrm{F}$, et al. Dental caries and bacterial load in saliva and dental biofilm of type 1 diabetics on continuous subcutaneous insulin infusion. J Appl Oral Sci 2018;26:e20170500.

https://doi.org/10.1590/1678-7757-2017-0500

16. Farooq MU, Mushtaq F, Naeem Z, Iqbal S, Naseem S, Ishtiaq O. Dietary habits and practices of type-2 diabetic patients in a tertiary care centre of Islamabad, Pakistan. J Pak Med Assoc 2018;68:825-30.

17.Harris D, McNicoll L, Epstein-Lubow G, Kali S Thomas P. HHS Public Access. Physiol Behav. 2017;176:139-48.

18. Thanh Ha N, Thi Phuong N, Thi Thu Ha L. How dietary intake of type 2 diabetes mellitus outpatients affects their fasting blood glucose levels? AIMS Public Heal 2019;6:424-36. https://doi.org/10.3934/publichealth.2019.4.424

19. Basil YAA, Rakan SAD. Oral hygiene practice of adult diabetic 
patients and their awareness about oral health problems related to diabetes. J Dent Oral Hyg 2017.

https://doi.org/10.5897/JDOH2017.0219

\section{KNOWLEDGE OF ORAL HEALTH IN PATIENTS WITH TYPE 1 DIABETES}

M. Vaičelionytė, K. Saldūnaitė, E.A. Bendoraitienė, J. Zūbienè, M. Žemaitienė, V. Andruškevičienė

Keywords: diabetes mellitus, oral health, oral hygiene. Summary

The aim of the study-to analyze the knowledge about oral health in patients with type one diabetes.

Materials and methods. The study was carried out at the Department of Endocrinology, Lithuanian university of health science of Kaunas clinics. 128 respondents were participating in this study. Research method - questionnaire. The study was conducted from December 2, 2019 to February 29, 2020. Random selection of participants was used in the research.

Results. Subjects with poor HbA1c were found to be statistically significantly more likely to respond with salivary dysfunction, gingivitis, and tooth decay symptoms more often than subjects with good HbA1c $(p<0.05)$. 65.4 percent of patients were found to eat irregularly. Only 4.7 percent of respondents brush their teeth after consuming carbohydrates, one-fifth ( 25.8 percent) brush their teeth once a day and one-third (31.3 percent) do not brush their interdental spaces. Half ( 46.9 percent) of respondents receive routine dental prophylaxis once a year. 43.8 percent of respondents are unaware that gum disease may affect glycemic control, 78.9 percent of respondents from dentists and 82.0 percent from oral hygienists never got an extra information about oral health care in diabetes and just 14.8 percent of respondents the family physician had recommended to visit oral health care specialists regularly.

Findings. Diabetic patients often experience symptoms of salivary dysfunction, tooth decay and gingivitis, and statistically significant links were found between $\mathrm{HbA} 1 \mathrm{c}$ control levels and oral health $(\mathrm{p}<0.05)$. Patients have poor dietary and oral hygiene habits and insufficient awareness of oral care in diabetics.

Correspondence to: meida.vaicelionyte@gmail.com

Gauta 2021-02-18 